\title{
Driving Forces of Total Factor Productivity in Europe ${ }^{1}$
}

\author{
Pavol OCHOTNICKÝ* - Martin ALEXY* - Marek KÁČER**
}

\begin{abstract}
In this paper, we explore the driving forces behind total factor productivity growth in 28 European countries in the period from 2005 to 2019. Based on neoclassical theory, theory of endogenous economic growth and competitiveness theory we formulate four research hypotheses related to the impact of technological readiness, human capital, business and tax environment and creativity on the TFP growth. We used fixed effects model focusing on the impact within the countries. Our results suggest that technological readiness is an important driving force behind TFP growth. We could only partially confirm the impact of the remaining explanatory variables.
\end{abstract}

Keywords: total factor productivity, TFP, economic growth, technology, human capital, creativity

JEL Classification: B40, C01, C50, E10, G28

DOI: https://doi.org/10.31577/ekoncas.2020.10.02

\section{Introduction}

One of the reasons which led to the increased interest in studying the driving forces of total factor productivity (TFP) was the slowdown in productivity, which began before the last financial and economic crisis. According to Remes et al. (2018), the increases in both labour productivity and TFP were not large

* Pavol OCHOTNICKÝ - Martin ALEXY, University of Economics in Bratislava, Faculty of National Economy, Department of Finance, Dolnozemská cesta 1, 85235 Bratislava 5, Slovakia; e-mail: pavol.ochotnicky@euba.sk; martin.alexy@euba.sk

** Marek KÁČER, University of Leeds, Leeds University Business School, Credit Management Research Centre, Accounting and Finance Division, Leeds, LS2 9JT, United Kingdom; University of Economics in Bratislava, Faculty of National Economy, Department of Finance, Dolnozemská cesta 1, 85235 Bratislava 5, Slovakia; e-mail: m.kacer@leeds.ac.uk

${ }^{1}$ The paper is the outcome of the research project Competitiveness, Economic Growth and Firm Survival (APVV-15-0322) supported by Slovak Research and Development Agency. 
enough. The productivity growth declined in last 15 years despite of rapid growth in technologies and development of AI (Syverson, 2017). Brynjolfsson, Rock and Syverson (2017) explain the modern productivity paradox is a symptom of the contemporary economy. They suggest that full effects of new technologies won't be realized until waves of complementary innovations are developed and implemented.

The maintaining of economic prosperity, competitiveness and sustainable growth through the TFP growth is among interests of political leaders. That is why it is important to clarify the drivers of TFP growth and form corresponding policies. A part of this effort is the creation of top institutional frameworks such as productivity or competitiveness councils to support the TFP growth. Also, creative industries are perceived as the special assets in global competitiveness by governments and legislators. ${ }^{2}$ Policies adopted in recent years in the EU include support for networking of creative people and support for cultural and creative industries to use advanced digital technologies ${ }^{3}$. These and other efforts have been a part of Europe 2020 Strategy and they combined different mechanisms to support economic growth and creation of new job opportunities based on creativity.

Aim of our paper is to identify the driving forces of TFP growth in Europe and estimate their impact. We combine several fundamental streams of literature, which significantly influenced further thinking about TFP, its driving forces and methodological approaches to TFP measurement. Most notably these are neoclassical theory (Hicks, 1932; Robinson, 1933; Solow, 1957), endogenous growth theory (Romer, 1994; Aghion and Howitt, 1992; Grossman and Helpman, 1991) and Porter's School of Management (Porter, 2000). We formulate and test four research hypotheses related to the impact of technological readiness, human capital, business and tax environment, and creativity. Using a panel dataset covering 28 European countries over the period from 2005 to 2019 and employing fixed effects methodology we estimate impact of selected determinants on TFP growth. Our findings suggest that technological readiness is significant determinant of TFP growth while we found only limited support for the hypotheses that higher education, paying taxes and creativity index are important driving forces, as well.

We contribute to the literature in two ways. We confirm that the important driving force behind TFP growth is technological readiness in times when impact of technological progress on economic growth is questioned by modern

\footnotetext{
${ }^{2}$ European cultural and creative sectors have been recognized as sources of economic growth and job opportunities (see further European Parliament, 2013).

${ }^{3}$ See further EC (2018).
} 
productivity paradox (Brynjolfsson, Rock and Syverson, 2017). Secondly, we focus on the impact within the countries and therefore our results may be useful for stakeholders keen to understand how changes in one of the considered predictors could influence future TFP growth in a country.

The paper is structured as follows. In the second section, we present an overview of key theories and empirical studies related to TFP. The research hypotheses are formulated in this part, as well. In the third section, we describe the variables and methodology used to address the research questions. In the fourth section, we describe and discuss the empirical findings. The last section concludes the study.

\section{Theoretical Foundations of TFP Sources and Literature Review}

In this section we provide overview of existing literature related to TFP driving forces seen through the lenses of neoclassical theories, theories of endogenous economic growth, competitiveness theory and other theories.

\subsection{TFP Driving Forces in Neoclassical Theories and Growth Models}

Solow (1957) explained the TFP based on the theory of economic growth and the Cobb-Douglas production function:

$$
Y=T F P^{*} K^{\alpha} * L^{1-\alpha}, \text { for } 0<\alpha<1
$$

where $Y$ is total output (value added), TFP is total productivity of production factors capital $(K)$ and labour $(L), \alpha$ is output elasticity of capital. Solow's main contribution is the explanation of TFP as a difference between the economic growth of country $(y)$ and the weighted growth of capital $(k)$ and growth of labour $(l)$ :

$$
\text { tfp }=y-\alpha * k-(1-\alpha) * l
$$

A higher level of TFP is achieved by higher production efficiency (Nadiri, 1970). Economic interpretation of the TFP is derived from the growth rate by which TFP contributes to economic growth in addition to growth caused by the increase in inputs.

Christensen, Jorgensen and Lau (1971) introduced a model of the four-factor translog production function, where they considered energy and material factors in addition to classical inputs (capital and labour) while including Hicks' neutral technical change as a function of time. Their model was adjusted by Ochotnický (1987; 2008), who addressed the high growth of energy intensity of the Slovak economy. Another example of the "incorporation" of a particular economic sector that is presumed to be a driving force of growth is suggested by Jorgenson 
et al. (2007). The authors developed and applied a model for analysing the effects of the penetration of information and communication technologies (ICT) on US economic growth through a multifactor translog production function. At the same time, they assumed that capital in the ICT sector and more educated ICT sector workforce make a higher contribution to productivity growth than the other sectors. Klas (2005) analysed the fundamental aspects of technological and innovative development and found that technology and innovation are basic factors of economic development.

As Aguirregabiria (2009) suggests there are several issues related to econometric testing of a suitable functional form of production function, thus also to technical progress and TFP. These are the problem of measuring output, errors in valuing the stock of capital, different quality of labour, the problem of model specification and correlation of inputs with unobservable productivity shocks, multicollinearity (labour and capital inputs are often correlated with each other). These issues can lead to biased econometric results and to less accurate economic analysis. Some studies question the plausibility of using the Cobb-Douglas production function for analysis (e.g. Burnside, Eichenbaum and Rebelo, 1996), while other ones supported it (e.g. Felipe and Adams, 2005). Havik et al. (2014) recognize the utility of using the Cobb-Douglas model and usefulness of a priori determination of parameter (1- $\alpha$ ) in equations (1) and (2) as a share of wages on value added.

\subsection{TFP Driving Forces in Theories of Endogenous Economic Growth}

This stream of the literature suggests that the driving force of economic growth is either the supply of human capital (Lucas, 1988) or investments into research and development (Romer, 1986). In addition, endogenous growth theories assume that technological progress is the driving force behind long-term economic growth (Uzawa, 1965; Lucas, 1988). At the same time, technological shifts in the economy are significantly dependent on the government's policy of supporting R\&D. Literature suggests a strong link between the TFP and the level of $R \& D$ measured either by the number of employees working in the R\&D sector or by R\&D expenditures (Romer, 1986; 1990; 1994; Aghion and Howitt, 1992; Grossman and Helpman, 1991). Romer (1994, p. 15) presents a model of long-term growth, in which knowledge is assumed to be the input of production and it increases the marginal productivity. The country's production and economic growth is the result of companies' investments in physical capital and labour, but also in R\&D expenditures, which increase the public stock of knowledge. He assumes that knowledge is the input of production and increases marginal productivity. Hence, he suggested the following model: 


$$
\mathrm{Y}=\mathrm{A}(\mathrm{RD}) * \mathrm{~F}(\mathrm{RD}, \mathrm{K}, \mathrm{L})
$$

where $\mathrm{Y}$ is output, $\mathrm{A}(\mathrm{RD})$ is a function of knowledge stock, $\mathrm{RD}$ is expenditure on $\mathrm{R} \& \mathrm{D}, \mathrm{K}$ is a stock of physical capital and $\mathrm{L}$ is a stock of labour.

The theory of endogenous growth defines human capital as the stock of knowledge and suggests that investment in human capital is one of the significant contributors to economic growth. According to Mankiw (1995) there is a limit to the maximum amount of human capital that an individual can accumulate. Therefore, endogenous growth models should focus more on understanding the process of basic research and technological development than on the accumulation of human capital.

\subsection{TFP Driving Forces in the Competitiveness Theory}

Porter $(1990 ; 1994)$ published one of the first concepts of the theory of competitiveness as so-called Porter's diamond. He originally studied the corporate competitiveness, but then realized the close interconnectedness of micro and macro levels. His model oriented on microeconomic factors includes the role of the state, too. Porter explains the economy's competitive advantage in certain industries based on four important factors or attributes. He describes them as determinants of national benefits; they either support or prevent the creation of a nation's competitive advantage. The four attributes are the Factor conditions (the nation's position in factors of production, such as skilled labour or infrastructure, necessary to compete in a given industry), Firm strategy, structure, and rivalry (the structure of companies and the intensity of domestic competition), Related and supporting industries (supporting industries supplying inputs crucial for innovation and internationalization of competitive conditions), and Demand conditions (the nature of home-market demand for the industry's product or service).

Porter expanded the original model with two additional attributes - government and opportunity. To recognize and seize opportunities such as new inventions, nations should create sufficient conditions (institutions, resources, human capital). Porter advocates that the only sensible concept and synthetic indicator for measuring competitiveness at the national level is overall productivity and its factors or drivers.

Porter (2000) does not see the role of governments in relation to TFP enhancement in the direct regulation of the economy, but in several modern tasks. For example, in supporting the most stable level of investment, in supporting technological change, ensuring the stability of the macroeconomic environment (inflation, exchange rate, public finances and others), in public intervention, especially in creating and supporting the quality of the business environment and 
service quality of public institutions. Porter's multidimensional view has also resulted in the permanent creation of competitiveness strategies, especially in the USA and Canada (Rugman, 2001), but also in monitoring the competitiveness of individual economies in international trade. The dependence between TFP and the quality of the institution was addressed by Tebaldi (2016). The study provides evidence that the quality of governments, institutional quality and openness of economy are important drivers of TFP growth. The relationship between the accumulation of human capital and the quality of institutions is also addressed by Glaeser, Lopez-de-Silanes and Shleifer (2004), while Pietrzak and Balcerzak (2016) attribute the growth of the quality of institutions to the growth of openness of economies within the EU countries. Findings of Stojcic and Tolic (2019) suggest that active government approach prevents decline of production and employment and rebuild trust in institutions.

\subsection{TFP Driving Forces in other Theories, Postulates and Selected Studies}

Florida (2002) developed the theory of creative capital from the theory of human capital. The theory of creative capital differs from the former, particularly in that it recognizes the specific type of human capital represented by creative people as a key factor in economic growth. Florida's theory assumes that in the knowledge economy, regions will benefit from mobilizing the best talent and resources available. Florida (2002) defines the creative class - scientists, engineers, architects, designers, writers, artists, musicians, lawyers, and people in specific occupations in education, health care, or business. The creativity of these individuals results in inventions and innovations in their work, which supports not only economic growth but also the growth of TFP.

According to Amann and Virmani (2015) massive digitization was the key factor that boosted productivity. However, it is limited due to shortcomings in key complementary factors and policies, companies' capabilities and assets, such as technical and managerial skills, organizational capital, innovation and financial capacity, policies that promote competition and the efficient redistribution of resources in the economy. Shortcomings in these additional factors have slowed the spread of digital technologies and reduced the potential impact of digitization on productivity. The theoretical basis of Amann and Virmani (2015) was the Romer's model (equation 3), where they distinguished the influence of R\&D in domestic capital and in foreign capital on TFP. The authors assume that there is a "feedback effect" of FDI on TFP growth in emerging economies via technology spill-overs across borders. The authors confirmed that FDI increase TFP growth and that the effects of FDI are much greater when investments in emerging economies come from developed and R\&D intensive countries. Some empirical 
studies hypothesise TFP as a multifactor function within various functional forms of production functions and subsequently attempt to determine factors of TFP growth. Gehringer, Martínez-Zarzoso and Nowak-Lehmann Danzinger (2015) used the dynamic OLS method to estimate the determinants of TFP for European countries. According to their results the main source of TFP growth is human capital, while ICT as a business-related service for the manufacturing production also has a positive effect. Openness with respect to non-EU countries has a negative and significant impact on TFP. Kataryniuk and Martínez-Martín (2019) studied the impact of commodity prices, demand and supply shocks on the growth of TFP in emerging economies. They found that TFP in commodity-dependent economies can explain changes in TFP due to the business cycle, with TFP growth in each country responding heterogeneously to changes in commodity prices.

\subsection{Development of Hypotheses}

Based on the theories described in the literature review we identified four potential driving forces of TFP - technological readiness, human capital, business environment and creativity. These concepts form the core of four hypotheses that will be tested empirically in the paper. We select a proxy for each conceptual variable and test its impact on the TFP growth in European countries.

The first and probably the decisive factor of the TFP growth is technological readiness and progress. It is correlated with expenditures on science and research, development of innovations, or their transfer from abroad, quality of capital stock, FDI quality, or degree of development of production technologies (Isaksson, 2007). In the academic literature, the positive impact of R\&D expenditures and innovations on TFP was confirmed also by Griffith (2000) and Ulku (2004). Syverson (2017) and Brynjolfsson, Rock and Syverson (2017) indicate that technological progress needs supportive environment with complementary innovations in order to be fully manifested in economic growth. We suppose that TFP growth is positively related to the level of technological readiness (hypothesis 1).

In addition to theoretical postulates, several studies have empirically confirmed generally accepted assumptions about the impact of investment in physical and human capital on TFP and economic growth (Mincer, 1974; Barro and Lee, 1993; Isaksson, 2002; Mastromarco and Zago, 2012). That is why the second potential determinant of TFP growth explored in the paper will be human capital, the endogenous component of which is workforce education, skills and talent, that may be gained through experience, practice and training. Again, we suppose that TFP growth is positively related to the quality of human capital (hypothesis 2).

Additional source and driving force of TFP growth is country's business framework and particularly tax mechanism which impacts the firm performance 
and thus economic growth. The business-friendly bureaucracy decreases costs incurred by firms, increase their profits and ultimately increase the value-added of the whole country. Plosser (1993) and Myles (2000) present the evidence for empirical link between taxation and growth. A widely-used policy to increase productivity is by giving tax incentives to $R \& D$ expenditure to stimulate privatesector innovative activity. ${ }^{4}$ We conjecture that the quality of business and tax environment is positively related to the TFP growth (hypothesis 3).

Theory of creative capital suggests that creativity is a key factor in economic growth. In the knowledge economy, not only the regions but also entire countries will gain an advantage if they create conditions for, attract and mobilize the best talents (Florida, 2002). Previous studies have demonstrated the cross-sectional correlation between the level of creative capital and the GDP per capita (Florida, Mellander and King, 2015) or the alternative measures of economic development such as Human development index or World Happiness index (Alexy, Káčer and Rehák, 2018). We assume that an increase in the creative capacity of a country should be positively associated with TFP growth (hypothesis 4).

\section{Dataset and Methodology}

We use panel data in the analysis with 28 European countries - these are 26 EU member states ( 25 current members + the UK) and Norway and Iceland. We use yearly data covering years $2005-2019$, although the panel is unbalanced. We aimed to collect the longest available data for each country and respective variables. The variables are briefly summarized and described in Table 1 along with their sources and concepts used for their computations.

T a ble 1

Description of Variables

\begin{tabular}{|c|c|c|}
\hline Variable name & Description & Source of original data \\
\hline TFP growth & $\begin{array}{l}\text { Dependent variable; computed as } \\
\text { a year-on-year growth rate of the total factor } \\
\text { productivity (TFP) }\end{array}$ & $\begin{array}{l}\text { European Commission, AMECO database, } \\
\text { total factor productivity: total economy } \\
\text { (ZVGDF) }\end{array}$ \\
\hline $\begin{array}{l}\text { Technological } \\
\text { readiness }\end{array}$ & $\begin{array}{l}\text { Explanatory variable; the proxy for driving } \\
\text { force technological readiness, the original } \\
\text { values of the variable were multiplied by } 10\end{array}$ & $\begin{array}{l}\text { World Economic Forum, Global } \\
\text { Competitiveness Index, } 9^{\text {th }} \text { pillar: } \\
\text { Technological readiness (GCI.B.09), value }\end{array}$ \\
\hline $\begin{array}{l}\text { Higher educa- } \\
\text { tion and training }\end{array}$ & $\begin{array}{l}\text { Explanatory variable; the proxy for driving } \\
\text { force human capital, the original values } \\
\text { of the variable were multiplied by } 10\end{array}$ & $\begin{array}{l}\text { World Economic Forum, Global } \\
\text { Competitiveness Index, } 5^{\text {th }} \text { pillar: Higher } \\
\text { education and training (GCI.B.05), value }\end{array}$ \\
\hline Paying taxes & $\begin{array}{l}\text { Explanatory variable; the proxy for driving } \\
\text { force business and tax environment }\end{array}$ & $\begin{array}{l}\text { World Bank, Doing Business Index, } \\
\text { Paying taxes (PAY.TAX.DB0616.DFRN) }\end{array}$ \\
\hline Creativity index & $\begin{array}{l}\text { Explanatory variable; the proxy for driving } \\
\text { force creativity, the original values were } \\
\text { multiplied by } 10\end{array}$ & $\begin{array}{l}\text { Alexy, Káčer and Rehák (2018), European } \\
\text { 3T Creativity Index }\end{array}$ \\
\hline
\end{tabular}

Source: Authors' elaboration. 


\subsection{Dependent Variable}

We use TFP data for the European countries computed and published by the European Commission in the AMECO database. Therein, the TFP is computed using the well-known Cobb-Douglas production function:

$$
G D P_{i, t}=T F P_{i, t} * L_{i, t}{ }^{\alpha_{i}} * K_{i, t}{ }^{1-\alpha_{i}}
$$

where GDP is the production output of a country $i$ measured as a gross domestic product at time $t$ at 2000 levels, TFP is the total factor productivity, $K$ is the net capital stock at 2000 levels and $L$ is the total employment. The parameter $\alpha$ is computed as an average of real unit labour costs over the longest available statistical period for the given country in the AMECO database (European Commission methodology). TFP is computed as a residual variable:

$$
T F P_{i, t}=G D P_{i, t} /\left(L_{i, t}^{\alpha_{i} *} K_{i, t}^{1-\alpha_{i}}\right)
$$

The published values are divided by the value of TFP in 2005 and multiplied by 100 . We use this variable and compute the year-on-year relative growth rate:

$$
g T F P_{i, t}=\left(T F P_{i, t}-T F P_{i, t-1}\right) / T F P_{i, t-1}
$$

The variable $g T F P_{i, t}$ is our dependent variable. In order to fully use the available time periods covered by the explanatory variables, we compute this variable for time periods $2006-2019 .^{5}$

\subsection{Explanatory Variables}

The first assumed driving force is technological readiness. As a proxy of this driving force, we use the $9^{\text {th }}$ pillar of Global Competitiveness Indicators published by the World Economic Forum - Technological readiness. The $9^{\text {th }}$ pillar combines the results of the Executive Opinion Survey and indicators published by the International Telecommunication Union. It combines the following areas: availability of latest technologies, firm-level technology absorption, FDI and technology transfer, internet users, fixed-broadband subscriptions, internet bandwidth and mobilebroadband subscriptions. This variable represents several dimensions related to the ability of the countries to adopt and make use of the current technologies, utilize

\footnotetext{
${ }^{4}$ Policymakers recognize the importance of the tax environment on economic growth. European Commission defined a growth-friendly tax structure as one of its main priorities in the area of tax policies (EC, 2011).

${ }^{5}$ Since, as will be explained in the following sub-section, in the model specifications the explanatory variables are one period lagged, this allows using the explanatory variables covering years from 2005 to 2018.
} 
the information and communication technologies (ICT) and conduct research and develop innovations and new technologies. The index covers the time-period $2008-2018$ and its values range between 0 and 10. In order to facilitate the comparison with other explanatory variables, we multiplied its values by 10 .

The second driving force behind TFP growth is human capital, traditionally measured by level of education (Woessmann, 2003). More broadly, it is described as a combination of factors such as education, experience and training which contribute to the value of a worker's marginal product (Frank and Bernanke, 2007). As a proxy variable for this driving force, we use the 5th pillar of the Global Competitiveness Indicators published by the World Economic Forum - Higher education and training. The $5^{\text {th }}$ pillar combines the data from UNESCO and the results of the Executive Opinion Survey. It combines the following areas: secondary education enrolment rate, tertiary education enrolment rate, quality of the system, quality of math and science education, quality of management schools, internet access in schools, local availability of specialized training services and extent of staff training. Similar to the previous variable, the index covers the time-period 2008 - 2018 and its values range between 0 and 10. The original values were multiplied by 10 and the transformed score used in this paper has a theoretical range from 0 to 100 .

The third driving force behind TFP growth is related to business and tax environment. The proxy variables used for this driving force is Paying taxes index included in Doing business index published by the World Bank. The Paying taxes index is being prepared in cooperation with $\mathrm{PwC}$. The index assesses the institutional and bureaucratic environment from the perspective of the process a medium-sized company must go through when paying taxes and mandatory contributions. The index combines several dimensions of the process including the number of payments a firm must make, time involved in preparing a filing, the total tax and contribution rate, a post-filing index (time involved in complying and completing corrections and reforms of the business environment. Hence, it reflects a well-balanced assessment of the institutional and business environment from a practical business point of view. The index covers the time period $2006-2016$ and its theoretical values range from 0 to 100.

Finally, the last driving force behind TFP growth assessed in this paper is the creativity. The proxy variable we selected for this driving force is the creativity index constructed in Alexy, Káčer and Rehák (2018). This index follows the $3 T$ concept put forward by Florida and Tinagli (2004) and comprises talent, technology and tolerance dimensions. It covers years $2005-2014$ and assumes values from 0 to 10. To compare the impact on the TFP growth with the remaining variables we multiplied the original values of the index by 10 to achieve range between 0 and 100 . 


\subsection{The Modelling Framework}

We use specification with a shift of the dependent variable to the next period since we expect explanatory variables to impact TFP with a lag. The models specified in this way can avoid the problem of endogeneity caused by the reverse causality or simultaneity between the explanatory and explanatory variables:

$$
g \operatorname{TFP}_{i, t+1}=f\left(\mathrm{~d}_{j, i, t}\right)
$$

As far as the modelling framework is concerned, there are three approaches to modelling the panel data - pooled regression, fixed effects and random effect estimators. The choice between the estimators depends on the objectives of the analysis and also whether the assumptions of the specific models are fulfilled. In this paper, we intend to elucidate how the changes in the specific variables within countries are related to changes in the TFP growth. Since our focus is to explain the variability within countries and not between them, the suitable modelling approach is the fixed effects estimator: ${ }^{6}$

$$
g T F P_{i, t+1}=a_{0}+a_{j} d_{j, i, t}+v_{i}+u_{i, t+1}
$$

where $a_{o}$ and $a_{j}$ are the parameters of the equation, $v_{\mathrm{i}}$ are fixed effects and $u_{\mathrm{i}, t+1}$ is an idiosyncratic random error. The parameters of the above model are estimated using within-estimator (the variables are transformed into the deviations from the means within the individual countries). In this specification, the fixed effects become nuisance parameters that are not estimated. Moreover, the estimated parameters are completely driven by the changes within the countries and thus are suitable for our analysis. ${ }^{7}$

\section{Results and Discussion}

Table 2 shows the descriptive statistics of the dependent and explanatory variables. For each variable, we denote the number of observations, mean, standard deviations, minimum and maximum values and also the time period covered in our dataset. As far as the dependent variable (TFP growth) is concerned, we note that its variability within the individual countries is three times greater than

\footnotetext{
${ }^{6}$ The suitability of the fixed effects estimator was also confirmed by tests of joint significance of the fixed effects and Hausman test. The results are not reported for the sake of brevity but are available from authors upon request.

${ }^{7}$ In unreported analyses using hybrid model (see Allison, 2009) we found that between-variability was not explained by our proxies of driving forces. One of the reasons may be that the TFP growth variability between countries is significantly smaller compared to its within variability.
} 
the variability between the countries and this fact further supports our focus on the statistical associations within countries. Interestingly, the situation is reversed as far as the explanatory variables are concerned in that here the within variability is smaller than that between the countries.

T a b l e 2

\section{Descriptive Statistics}

\begin{tabular}{|l|c|c|c|r|c|c|c|c|}
\hline Variable & N & \multicolumn{1}{c|}{ Mean } & \multicolumn{1}{c|}{ SDo } & \multicolumn{1}{c|}{ SDb } & SDw & Min & Max & Time period \\
\hline TFP growth & 392 & 0.005 & 0.027 & 0.008 & 0.026 & -0.121 & 0.242 & $2006-2019$ \\
Technological readiness & 308 & 51.947 & 7.578 & 6.670 & 3.794 & 31.078 & 64.567 & $2008-2018$ \\
Higher education & 308 & 51.580 & 5.225 & 5.046 & 1.634 & 39.911 & 62.654 & $2008-2018$ \\
Paying taxes & 307 & 76.646 & 11.324 & 10.080 & 5.483 & 42.440 & 95.280 & $2006-2016$ \\
Creativity index & 280 & 45.471 & 20.949 & 21.140 & 2.522 & 11.825 & 87.136 & $2005-2014$ \\
\hline
\end{tabular}

Notes: The table shows descriptive statistics for the dependent variable and explanatory variables from the models estimated in the study. TFP growth stands for the year-on-year rate of growth of TFP, the remaining variables are described in Table 1. SDo stands for overall standard deviation, SDb stands for standard deviation between country means and SDw for the standard deviation of deviations from country means. We used all data available for each variable.

Source: Authors' elaboration.

Table 3

\section{Collinearity Diagnostics}

Panel A: Pearson's Correlation Coefficients

\begin{tabular}{|l|l|c|c|c|c|}
\hline & & $\mathbf{1}$ & $\mathbf{2}$ & $\mathbf{3}$ & $\mathbf{4}$ \\
\hline 1 & Technological readiness & 1.000 & & & \\
2 & Higher education & $0.780^{*}$ & 1.000 & & \\
3 & Paying taxes & $0.877^{*}$ & $0.805^{*}$ & 1.000 & \\
4 & Creativity index & $0.672^{*}$ & $0.546^{*}$ & $0.598^{*}$ & 1.000 \\
\hline
\end{tabular}

Panel B: Variance Inflation Factors

\begin{tabular}{|l|c|c|c|}
\hline & VIF & Tolerance & $\mathbf{R}^{\mathbf{2}}$ \\
\hline Technological readiness & 4.983 & 0.201 & 0.799 \\
Higher education & 4.645 & 0.215 & 0.785 \\
Paying taxes & 7.639 & 0.131 & 0.869 \\
Creativity index & 1.828 & 0.453 & 0.453 \\
\hline
\end{tabular}

Panel C: Condition Number

\begin{tabular}{|l|c|c|}
\hline & Eigenvalue & Condition index \\
\hline 1 & 4.884 & 1.000 \\
2 & 0.102 & 6.926 \\
3 & 0.009 & 23.094 \\
4 & 0.004 & 35.833 \\
5 & 0.001 & 62.154 \\
Condition number & & 62.154 \\
\hline
\end{tabular}

Notes: Panel A shows the Pearson's correlation coefficients among the explanatory variables. The asterisk denotes the correlation coefficients statistically significant at the 5\% significance level. Panel B shows the variance inflation factors. Panel $\mathrm{C}$ shows eigenvalues, condition indices and condition number calculated from scaled SSCP (sum of squared cross-product) matrix with intercept.

Source: Authors' elaboration. 
Table 3 presents results of various collinearity diagnostics. The Pearson's pairwise correlation coefficients suggest high degree of collinearity since all of them are higher than 0.5. Even though VIFs (variance inflation factors) do not indicate multicollinearity issue (all VIFs are smaller than 10), the condition number does (value is higher than 30).

Due to higher degree of multicollinearity among explanatory variables, in the first step, we tested our hypothesis using bivariate models. As the second step, we estimated a model with all explanatory variables. Estimated coefficients seem to exhibit typical symptoms of high degree of multicollinearity such as insignificant and unstable estimated coefficients with flipping signs. That is why, in the third step, we utilized ridge regression approach to deal with multicollinearity. For comparison with other results we present the model with optimal penalty parameter (lambda). The estimation results are reported in Table 4.

Table 4

\section{Estimation Results}

\begin{tabular}{|c|c|c|c|c|c|c|}
\hline & Model 1 & Model 2 & Model 3 & Model 4 & Model 5 & Model 6 \\
\hline $\begin{array}{l}\text { Technological } \\
\text { readiness }\end{array}$ & $\begin{array}{c}0.00311 * * * \\
(8.85)\end{array}$ & & & & $\begin{array}{c}0.00540^{* * * *} \\
(4.22)\end{array}$ & $\begin{array}{c}0.00537 * * * \\
(5.26)\end{array}$ \\
\hline Higher education & & $\begin{array}{c}0.00328 * * * \\
(3.50)\end{array}$ & & & $\begin{array}{c}-0.00293 \\
(-1.36)\end{array}$ & $\begin{array}{c}-0.00260 \\
(-1.42)\end{array}$ \\
\hline Paying taxes & & & $\begin{array}{c}0.000780 \text { *** } \\
(3.46)\end{array}$ & & $\begin{array}{c}-0.000590 \\
(-0.95)\end{array}$ & $\begin{array}{c}-0.000551 \\
(-0.93)\end{array}$ \\
\hline Creativity index & & & & $\begin{array}{c}0.00173 * * \\
(2.42)\end{array}$ & $\begin{array}{c}0.00169 \\
(0.89)\end{array}$ & $\begin{array}{c}-0.000245 \\
(-0.17)\end{array}$ \\
\hline Intercept & $\begin{array}{c}-0.117 * * * * \\
(-8.09)\end{array}$ & $\begin{array}{c}-0.133 * * * \\
(-3.24)\end{array}$ & $\begin{array}{c}-0.0355^{* * *} * \\
(-2.77)\end{array}$ & $\begin{array}{c}-0.0187^{*} \\
(-1.83)\end{array}$ & $\begin{array}{c}-0.0740 \\
(-0.80)\end{array}$ & $\begin{array}{c}-0.0641 \\
(-0.88)\end{array}$ \\
\hline Observations & 308 & 308 & 307 & 280 & 196 & 196 \\
\hline $\mathrm{R}^{2}$ (within) & 0.210 & 0.043 & 0.023 & 0.022 & 0.248 & 0.239 \\
\hline $\begin{array}{l}\text { Estimation } \\
\text { method }\end{array}$ & $\mathrm{FE}$ & $\mathrm{FE}$ & $\mathrm{FE}$ & $\mathrm{FE}$ & $\mathrm{FE}$ & $\begin{array}{c}\text { Ridge } \\
\text { regression }\end{array}$ \\
\hline
\end{tabular}

Notes: The dependent variable in all the presented models is the TFP growth. The asterisks denote the statistical significance of the estimated coefficients $(* 10 \%, * * 5 \%, * * * 1 \%)$. The first five models are estimated using fixed effects estimator with standard errors clustered in countries. The last model specification is estimated using ridge regression and dummy variable approach with optimal penalty parameter lambda $\left(\lambda^{*}=10^{-2.1}\right)$ determined by leave-one-out cross-validation method.

Source: Authors' elaboration.

The estimation results of simple bivariate models (model 1 to model 4 in Table 4) support the assumption that each of the selected variables impacts TFP growth in a positive way. Also, each model is statistically significant. A onepoint increase in the transformed technological readiness score within an individual country is associated with 0.31 percentage point increase in TFP growth in the following year. The model explains $21 \%$ of TFP growth variability within the countries (model 1). A one-point increase in the transformed GCI higher 
education score is associated with 0.33 percentage point increase in the TFP growth, the within- $\mathrm{R}^{2}$ is just over $4 \%$ (model 2 ). An increase of one point in the paying taxes score is associated with less than 0.1 percentage point increase in the TFP growth, while model explains about $2 \%$ of the within variability (model 3). An increase of one point in the transformed creativity index is associated with 0.17 percentage point increase in the TFP growth, the within- $\mathrm{R}^{2}$ is slightly more than $2 \%$ (model 4$)^{8}$

The results of bivariate models provide preliminary confirmation of our hypotheses, but it is important to explore how our explanatory variables interact in a multivariate model. The results of the multivariate model (model 5 in Table 4) indicate that the only variable impacting TFP growth is technological readiness, while the remaining variables are not statistically significant, some of them even attracting the opposite sign. The magnitude of effect of technological readiness is even higher than in the bivariate model (model 1 ) when it was the only predictor, but this can be caused by shorter time-period.

\subsection{Sensitivity Analysis}

The high degree of multicollinearity among explanatory variables could be the reason of observed results in multivariate model. To explore this issue further we employ ridge regression ${ }^{9}$ which was suggested as one of the ways to deal with the issue of multicollinearity (Hoerl, 1962). That is why, as a sensitivity analysis we have estimated ridge regression models for the penalty parameter ranging from $10^{-7}$ to $10^{3}$.

Figure 1 displays the trajectory of estimated coefficients of explanatory variables across different values of penalty parameter. The range of models starts with the fixed effect model $\left(\lambda=10^{-7}\right)$ and ends with convergence to naïve model including only the intercept $\left(\lambda=10^{3}\right)$. Model with optimal lambda $\left(\lambda^{*}=10^{-2.1}\right)$ obtained by leave-one-out cross-validation method is indicated in the Figure 1 with vertical line.

Estimation results of the ridge regression model using the optimal lambda is reported in the last column of Table 4 . In the model, the only statistically significant variable is technological readiness and qualitatively same results are

\footnotetext{
${ }^{8}$ The relative impact of the explanatory variables on the TFP growth cannot be compared based on bivariate models $1-4$.

${ }^{9}$ The multicollinearity causes the matrix $X^{T} X$ to be ill conditioned, i.e. because of near perfect collinearity of explanatory variables the determinant of the matrix is close to zero and this causes instability of its inverse needed to compute the OLS estimator $\hat{\beta}=\left(X^{T} X\right)^{-1} X^{T} y$. The ridge regression estimator addresses the issue by adding a small penalty parameter $\lambda$ to the diagonal elements of the $X^{T} X$ matrix, i.e. $\hat{\beta}(\lambda)=\left(X^{T} X+\lambda I\right)^{-1} X^{T} y$.
} 
obtained across all ridge regression models. Thus, the sensitivity analysis confirmed that TFP growth can be explained by technological readiness as the most important determinant from among the considered explanatory variables.

Figure 1

\section{Ridge Regression Coefficients}

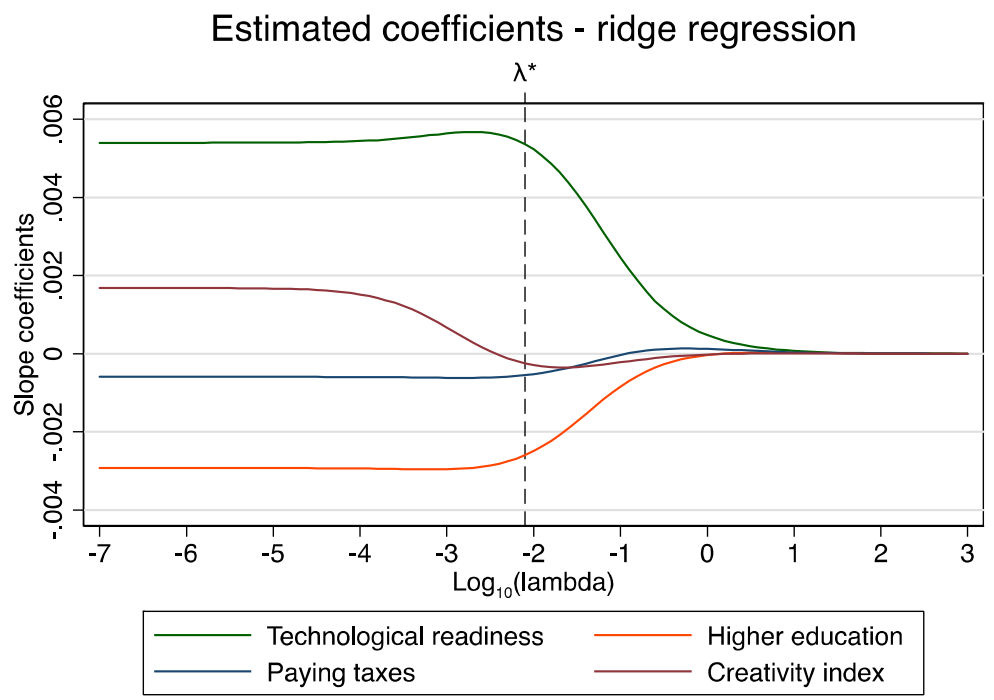

Notes: The figure shows the estimated coefficients as a function of penalty parameter lambda. The vertical dashed line shows the model with the optimal lambda $\left(\lambda^{*}=10^{-2.1}\right)$ using leave-one-out cross-validation method. Source: Authors' elaboration.

\subsection{Discussion}

Based on our results we can confirm hypothesis 1 as the technological readiness seems to be the most important driving force for TFP growth. If a country does not keep up with the newest technological developments then it may fall behind other countries in the near future with respect to TFP growth. This finding is consistent with the proposition of Lucas (1988) and is supportive of the view of theories of endogenous economic growth on the significance of the technological change. Our finding seems to support one of the predictions of Andersson et al. (2018), who analysed factors of growth in the post-crisis period, and suggest that digital production and supply chains as current technological advancements which may raise TFP in the near future, because of the greater efficiency. They indicate that one reason for the slowdown of TFP growth in the prior-crisis period is that it takes longer for technological innovations by pioneering firms to be incorporated into the production processes of other firms and therefore technological readiness could speed the absorption process across the economy. 
Other three hypotheses can be confirmed only partially based on results of bivariate models, lacking stronger evidence from multivariate models. Explanatory variables are statistically correlated and we can agree they are interconnected based on roles they play in facilitating economic growth. Even though their mutual impact cannot be isolated in our multivariate models, they measure different qualities and attributes of economic environment. Our results suggest that human capital (represented by higher education and training proxy) has positive impact on TFP growth. Griliches (1979) suggests that companies strive to acquire new economic knowledge and human capital for their innovative activities. Audretsch and Feldman (1996) found that the knowledge gained from university research brings economic benefits to commercial innovation by private companies through spillover. Knowledge spillover effects are considered to be an important mechanism of endogenous growth (Lucas, 1988). Such transmission mechanism indicates the link between human capital and technological progress through innovations. However we would claim that investing into technological readiness cannot substitute investments into human capital.

Business and tax environment (represented by index Paying taxes) seems to have impact on TFP growth, although its effect appears to be smaller compared to the human capital. We find some evidence in support of Porter's growth attribute Government (creation of sufficient conditions through institutions, resources and human capital). We suppose that if a country does not strive sufficiently to reach stable institutional and business environment it may threaten the TFP growth.

Our findings indicate that creativity (measured by multidimensional index) has positive impact on TFP growth to similar degree as business and tax environment. Each economy has its creative capacity or creative potential and they are determined by diverse components (Alexy, Káčer and Rehák, 2018). We suppose that such country specific characteristics of creativity can facilitate further TFP growth through innovations, creative clusters and new opportunities. Boschma and Fritsch (2009) found that job opportunities were closely connected with concentration of the creative people. Our findings indicate that countries would benefit from advancement of their individual creativity stimulating further TFP growth.

\section{Conclusion}

In this study, we explore the driving forces behind total factor productivity growth in 28 European countries in years 2005 - 2019. We formulate four research hypotheses related to the impact of technological readiness, human capital, business and tax environment and creativity on the TFP growth based on neoclassical theory, theory of endogenous economic growth and competitiveness theory. 
We used fixed effects model focusing on the impact of TFP growth predictors within the countries. The overall estimation results confirmed the theoretical assumptions about the driving forces of TFP growth. The common finding is that technological readiness is an important driver of TFP growth, thus confirming hypothesis 1 . This outcome is verified by the sensitivity analysis employing ridge regression. Technological readiness could be a suitable response to modern productivity paradox similar to finding of Brynjolfsson, Rock and Syverson. (2017). It is not self-evident that technological progress would automatically lead to TFP growth as indicated by Andersson et al. (2018). Other three hypotheses can be confirmed only partially based on results of bivariate models, lacking stronger evidence from multivariate models.

Even though the empirical research reported in this paper has contributed to our understanding of the driving forces behind the TFP growth, it is not without limitations. Firstly, the selected proxies might not completely represent the intended driving forces of TFP growth. Secondly, the strong multicollinearity among the available explanatory variables is another limiting factor. Perhaps a longer time-series dimension of the panel data would eliminate the extent of multicollinearity among the explanatory variables. Thirdly, judging by the relatively small explanatory power of some of the models we could have omitted important predictors of TFP growth. All the above-mentioned points could prove a fruitful avenue for future research efforts.

\section{References}

AGHION, P. A. - HOWITT, P. (1992): A Model of Growth. Through Creative Destruction. Econometrica, 60 , No. 2 , pp. $323-351$.

AGUIRREGABIRIA, V. (2009): Econometric Issues and Methods in the Estimation of Production Functions. [MPRA Paper, No. 15973.] Munich: MPRA.

ALEXY, M. - KÁČER, M. - REHÁK, Š. (2018): Creative Capacity of European Countries. Hungarian Geographical Bulletin, 67, No. 3, pp. $201-222$.

ALLISON, P. D. (2009): Fixed Effects Regression Models. Thousand Oaks: SAGE.

AMANN, E. - VIRMANI, S. (2015): Foreign Direct Investment and Reverse Technology Spillovers: The Effect on Total Factor Productivity. OECD Journal: Economic Studies, Vol. 2014, No. 1 , pp. $129-153$.

ANDERSSON, M. - SZÖRFI, B. - TÓTH, M. - ZORELL, N. (2018): Potential Output in the Post-Crisis Period. [ECB Economic Bulletin, 7.] Frankfurt am Main: ECB.

AUDRETSCH, D. B. - FELDMAN, M. P. (1996): R\&D Spillovers and the Geography of Innovation and Production. American Economic Review, 86, No. 4, pp. 253 - 273.

BARRO, R. - LEE, J. (1993): International Comparisons of Educational Attainment. [NBER Working Paper No. 4349.] Cambridge, MA: NBER.

BOSCHMA, R. - FRITSCH, M. (2009): Creative Class and Regional Growth: Empirical Evidence from Seven European Countries. Economic Geography, 85, No. 4, pp. 391 - 423. 
BRYNJOLFSSON, E. - ROCK, D. - SYVERSON, C. (2017): Artificial Intelligence and the Modern Productivity Paradox: A Clash of Expectations and Statistics. [NBER Working Paper No. 24001.] Cambridge, MA: NBER.

BURNSIDE, A. C. - EICHENBAUM, M. S. - REBELO, S. T. (1996): Sectoral Solow Residuals. European Economic Review, 40, No. 3 - 5, pp. 861 - 869.

EC (2018): European Creative Hubs Network Project Evaluation Summary Report, May. Brussels: European Commission.

EUROPEAN PARLIAMENT (2013): European Parliament Resolution P7_TA-2013-0368 on Promoting the European Cultural and Creative Sectors as Sources of Economic Growth and Jobs. Strasbourg, 12 September.

FLORIDA, R. (2002): The Rise of the Creative Class: And How Its Transforming Work, Leisure, Community and Everyday Life. New York: Basic Books.

FLORIDA, R. - TINAGLI, I. (2004): Europe in the Creative Age. London: Demos.

FLORIDA, R. - MELLANDER, C. - KING, K. (2015): The Global Creativity Index. Toronto: Martin Prosperity Institute.

FRANK, R. - BERNANKE, B. (2007): Principles of Economics. Third Edition. New York: McGraw-Hill/Irwin.

GEHRINGER, A. - MARTÍNEZ-ZARZOSO, I. - NOWAK-LEHMANN DANZINGER, F. (2016): What are the Drivers of Total Factor Productivity in the European Union? Economics of Innovation and New Technology, 25, No. 4, pp. $406-434$.

GLAESER, E. L. - LOPEZ-de-SILANES, P. F. - SHLEIFER, A. (2004): Do Institutions Cause Growth? Journal of Economic Growth, 9, pp. $271-303$.

GRILICHES, Z. (1979): Issues in Assessing the Contribution of Research and Development to Productivity Growth. The Bell Journal of Economics, 10, No. 1, pp. $92-116$.

GRIFFITH, R. (2000): How Important Is Business R\&D for Economic Growth and Should the Government Subsidise It? London: Institute for Fiscal Studies.

GROSSMAN, G. M - HELPMAN, E. (1991): Quality Ladders in the Theory of Growth. The Review of Economic Studies, 58, No. 1, pp. $43-61$.

FELIPE, J. - ADAMS, F. G. (2005): "A Theory of Production". The Estimation of the CobbDouglas Function: A Retrospective View. Eastern Economic Journal, 31, No. 3, pp. 427 - 445.

HICKS, J. R. (1932): The Theory of Wages. London: Macmillan.

HAVIK, K. - MCMORROW, K. - ORLANDI, F. - PLANAS, C. - RACIBORSKI, R. - RÖGER, W. - ROSSI, A. - THUM-THYSEN, A - VANDERMEULEN, V. (2014): The Production Function Methodology for Calculating Potential Growth Rates \& Output Gaps. [Economic Papers 535.] Brussels: European Union.

CHRISTENSEN, L. J. - JORGENSEN, O. W. - LAU, L. (1971): Conjugate Duality and the Transcendental Logarithmic Production Function. Econometrica, 39, No. 4, pp. 255 - 256.

ISAKSSON, A. (2002): The Importance of Human Capital for the Trade - Growth Link. Vienna: Statistics and Information Networks Branch of UNIDO.

ISAKSSON, A. (2007): Determinants of Total Factor Productivity: A Literature Review. Vienna: Research and Statistics Branch United Nations Industrial Development Organization (UNIDO).

JORGENSON, D. W. - HO, M. S. - SAMUELS, J. D. - STIROH K. J. (2007): Industry Origins of the American Productivity Resurgence. Economic systems research, 19, No. 3, pp. $229-252$.

KATARYNIUK, I. - MARTÍNEZ-MARTÍN, J. (2019): TFP Growth and Commodity Prices in Emerging Economies. Emerging Markets Finance and Trade, 55, No. 10, pp. 2211 - 2229.

KLAS, A. (2005): Technológia a inovácie ako základný faktor ekonomického rozvoja. Ekonomický časopis/Journal of Economics, 53, No. 6, pp. 576- 592.

LUCAS, R. E. (1988): On the Mechanics of Economic Development. Journal of Monetary Economics, 22, No. 1, pp. 3-39.

MANKIW, N. G. (1995): The Growth of Nations Brookings Papers on Economic Activity. 25th Anniversary Issue, 26, No. 1, pp. 275 - 326 
MASTROMARCO, C. - ZAGO, A. (2012): On Modeling the Determinants of TFP Growth. Structural Change and Economic Dynamics, 23, No. 4, pp. $373-382$.

MINCER, J. (1974): Progress in Human Capital Analyses of the Distribution of Earnings. [NBER Working Paper, No. 53.] Cambridge, MA: NBER.

MYLES, G. D. (2000): Taxation and Economic Growth. Fiscal Studies, 21, No. 1, pp. $141-168$.

NADIRI, M. I. (1970): Some Approaches to the Theory and Measurement of Total Factor Productivity: A Survey. Journal of Economic Literature, 8, No. 4, pp. 1137 - 1177.

OCHOTNICKÝ, P. (1987): Meranie substitučných procesov v ekonomike SR pomocou transcendentálnej logaritmickej produkčnej funkcie. Informačné systémy, 1987/4.

OCHOTNICKÝ, P. (2008): Výber produkčnej funkcie pri odhade potenciálneho produktu. Ekonomický časopis/Journal of Economics, 56, No. 8, pp. 800 - 815.

PLOSSER, C. (1993): The Search for Growth. Policies for Long Run Growth, Symposium Series. Kansas City: Federal Reserve of Kansas City.

PIETRZAK, M. - BALCERZAK, A. (2016): Quality of Institutions and Total Factor Productivity in European Union. Statistics in Transition New Series, 17, No. 3, pp. 497 - 514.

PORTER, M. E. (1990): The Competitive Advantage of Nations. New York: Free Press.

PORTER, M. E. (1994): The Role of Location in Competition. International Journal of the Economics of Business, 1 , No. 1, pp. $35-40$.

PORTER, M. E. (2000): Location, Competition, and Economic Development: Local Clusters in a Global Economy. Economic Development Quarterly, 14, No. 1, pp. 15 - 34.

ROBINSON, J. (1933): Imperfect Competition, Essays in the Theory of Employment, Introduction to the Theory of Employment. First Edition. London: Macmillan and CO., Limited St. Martin's Street.

ROMER, P. (1986): Increasing Returns And Long-Run Growth. Journal of Political Economy, 94, No. 5, pp. 1002 - 1037.

ROMER, P. (1990): Endogenous Technological Change. Journal of Political Economy, 98, No. 5, pp. S71 - S102.

ROMER, P. (1994): The Origins of Endogenous Growth. Journal of Economic Perspectives, 8, No. 1 , pp. $3-22$.

REMES, J. - MANYIKA, J. - BUGHIN, J. - WOETZEL, J. - MISCHKE, J. - KRISHNAN, M. (2018): Solving the Productivity Puzzle: The Role of Demand and the Promise of Digitization. McKinsey Global Institute.

RUGMAN, A. M. (2001): The Impact of Globalisation on Canadian Competition Policy - To be presented at the Toronto Conference on "Canadian Competition Policy: Preparing for the Future", June 18 - 20, 2001 sponsored by the Richard Ivey School of Business Industry Canada and the Bureau of Competition Policy.

SOLOW, R. M. (1957): Technical Change and the Aggregate Production Function. The Review of Economics and Statistics, 39, No. 3, pp. $312-320$.

STOJCIC, N. - TOLIC, M. (2019): Direct and Indirect Effects of Fiscal Decentralization on Economic Growth. Ekonomický časopis/Journal of Economics, 67, No. 3, pp. 280 - 306.

SYVERSON, C. (2017): Challenges to Mismeasurement Explanations for the US Productivity Slowdown. Journal of Economic Perspectives, 31, No. 2, pp. $165-186$.

TEBALDI, E. (2016): The Dynamics of Total Factor Productivity and Institutions. Journal of Economic Development, 41, No. 4, pp. $1-25$.

ULKU, H. (2004): R\&D, Innovation, and Economic Growth: An Empirical Analysis. [WP/04/185.] Washington, DC: International Monetary Fund.

UZAWA, H. (1965): Optimum Technical Change in an Aggregative Model of Economic Growth. International Economic Review, 6, No. 1, pp. 18 - 31.

WOESSMANN, L. (2003): Specifying Human Capital. Journal of Economic Surveys, 17, No. 3 , pp. $239-270$ 